\title{
Analisis Pembelajaran Tari Tradisional Penthul Melikan pada Anak Usia 4-6 Tahun
}

\author{
Lilik Dwi Kurniawati, Elisa Novie Azizah \\ PG PAUD STKIP Modern Ngawi \\ lilikdwikurniawati@gmail.com, elisanovie3@gmail.com
}

\begin{abstract}
Abstrak
Penelitian ini bertujuan untuk mendeskripsikan: perencanaan, pelaksanaan, dan kendalakendala yang dialami selama proses pembelajaran tari tradisional Penthul Melikan pada anak usia 4-6 tahun di sanggar Penthul Melikan. Metode penelitian yang digunakan adalah kualitatif deskriptif. Teknik pengumpulan data yang dilakukan adalah observasi, wawancara, dan studi dokumentasi. Hasil penelitian menunjukkan bahwa: 1) perencanaan dalam pembelajaran tari tradisional Penthul Melikan di sanggar Penthul Melikan: pelatih menentukan tujuan pembelajaran, alat dan bahan, alokasi waktu, materi, dan langkah-langkah pembelajaran; 2) pelaksanaan terdiri dari: kegiatan pembukaan yaitu pelatih mengkondisikan anak dan menyampaikan materi yang akan dilaksanakan serta mengingat materi yang telah dilaksanakan sebelumnya, kegiatan inti yaitu anak memperhatikan rekaman video tari tradisional Penthul Melikan, pelatih memberikan contoh gerakan tari lalu diikuti oleh anak, dan menjelaskan makna gerakan tari, kegiatan penutup yaitu pelatih memberikan penguatan dan pesan terkait materi yang telah dilaksanakan; 3) Kendala internal: kurang komunikasi antara pelatih dan anak, kemampan anak yang berbeda, terdapat gerakan yang sulit yaitu gerakan III, eksternal yaitu cuaca dan tidak ada raport untuk hasil belajar anak.
\end{abstract}

Kata Kunci : Pembelajaran, Tari Tradisional, Penthul Melikan, Anak Usia 4-6 Tahun.

\section{PENDAHULUAN}

Masa anak usia dini merupakan masa keemasan atau sering disebut masa golden age, biasanya ditandai oleh perubahan cepat dalam perkembangan fisik, kognitif, sosial, dan emosional. Berdasarkan hasil studi longitudinal Bloom (Juntika Nurikhsan, 2007) menyebutkan bahwa pada usia 4 tahun kapasitas kecerdasan sudah mencapai $50 \%$, usia 8 tahun mencapai $80 \%$ dan usia 13 tahun mencapai 92\%. Pada masa usia dini merupakan masa terjadinya kematangan fungsi-fungsi fisik dan psikis yang siap merespon stimulasi (rangsangan) yang diberikan oleh lingkungan. Masa ini merupakan masa untuk meletakkan dasar pertama dalam mengembangkan potensi fisik (motorik), intelektual, emosional, sosial, bahasa, moral spiritual, dan seni.
Perkembangan seni pada anak dapat distimulus melalui pembelajaran tari. Tari adalah ekspresi jiwa yang media ungkapnya gerak tubuh. Gerak yang digunakan untuk mengekspresikan isi hati merupakan gerak yang sudah diolah sehingga sesuai dengan tema, maksud, dan tujuan atau isi tarian. Gerak merupakan medium utama dalam tari. Gerak tari adalah sebuah proses perpindahan dari satu sikap tubuh yang satu ke sikap tubuh yang lain. Dengan kenyataan tersebut maka gerak dapat dipahami sebagai kenyataan visual (Hidayat, 2005). Menari membentuk anak untuk memiliki kemampuan mengkoordinasikan gerak satu dengan gerak berikutnya dan gerak dengan musik atau irama yang mengiringi tarian. Dengan kata lain menari dapat melatih gerak tubuh anak menjadi lebih baik, baik itu dari aspek pertumbuhan fisik maupun koordinasi gerak. 
Pendidikan seni tari dapat melatih keterampilan dan koordinasi gerak anak sekaligus sebagai sarana untuk memperkenalkan, membudayakan dan menanamkan nilai-nilai seni budaya bangsa. Pendidikan seni tari yang termasuk didalamnya gerak dan lagu diberikan kepada anak usia dini agar mempunyai kemampuan dasar yang mencakup persepsi, pengetahuan, apresiasi dan pemahaman. Kemampuan dasar tersebut, diharapkan dapat memberikan kemampuan mengekspresikan diri untuk menyeimbangkan fungsi otak kiri dan kanan, dengan memadukan unsur logika,etika dan estetika. Selain hal tersebut pembelajaran seni tari juga ditujukan untuk menumbuhkembangkan kesadaran sikap menghargai, toleran, demokratis, beradab, dan hidup rukun dengan sesama (Hartono: 2012).

Tari sebagai sebuah kesenian tumbuh mengikuti perkembangan zaman yang selalu dipengaruhi kebutuhan hidup yang beranekaragam dan kemudian menuntut terjadinya perubahan nilai yang berlaku di masyarakat sebagai pelaku seni tersebut. Tari juga hadir dan berfungsi dan berperan pada lingkungan tertentu yang memiliki adat istiadat dan tata masyarakat. Menurut Yayat Nursantara (2007) tari dapat dibagi menjadi beberapa kelompok, diantaranya tari tradisional, tari nusantara, tari kreasi, dan tari kontemporer. Diantara kesemua jenis tari yang ada, tari tradisional merupakan jenis tari yang perjalanan perkembangannya paling lama karena dilakukan dengan berpegang pada pola tertentu yang sudah mentradisi.

Tari tradisional merupakan jenis tarian yang telah ada sejak lama dan diwariskan secara turun temurun, dari generasi satu ke generasi berikutnya. Menurut Yayat Nursantara (2007) secara umum biasanya tari tradisional mengandung nilai filosofis, simbolis, dan religius. Semua aturan ragam gerak, formasi, busana, dan riasnya tidak banyak berubah. Untuk melestarikan kebudayaan daerah seperti tari tradisional, maka tari tradisional perlu dikenalkan dan diajarkan pada anak sejak dini.

Pembelajaran tari tradisional pada anak usia dini menjadi salah satu cara menjaga dan melestarikan budaya daerah. Melalui pembelajaran tari tradisional, nilai-nilai kebudayaan dapat tertanam pada diri anak bangsa. Seperti halnya pembelajaran tari tradisional Penthul Melikan yang berasal dari Kota Ngawi merupakan salah satu aset untuk mengembangkan dan melestarikan budaya setempat.

Fakta di lapangan, tari tradisional Penthul Melikan diwajikan dalam pembelajaran pendidikan anak usia dini di Kabupaten Ngawi. IGTKI sebagai wadah pengembangan pendidikan Taman Kanak-kanak memiliki suatu program kerja, untuk memperingati hari Ulang Tahun IGTKI mengadakan pertunjukan tari tradisional Penthul Melikan secara massal di lapangan merdeka Ngawi. Dalam pelaksanaanya, setiap lembaga pendidikan anak usia dini di Kabupaten Ngawi wajib ikut serta dalam kegiatan pertunjukan tari tradisional Penthul Melikan. Namun kemampuan anak dalam melakukan pembelajaran tari tradisional Penthul Melikan masih rendah. Hal ini terlihat anak masih mengalami kesulitan dalam beberapa gerakan antara lain kurang serasi saat melakukan gerakan awal tari dimulai. Saat peralihan satu gerakan ke gerakan berikutnya, masih belum kompak. Penggunaan topeng kayu sebagai ciri khas dalam pelaksanaan tari tradisional Penthul Melikan membuat anak mengalami kesulitan saat menari. Guru dalam mempelajari tari tradisional Penthul Melikan masih mengalami kendala yaitu minimnya pelatihan tari tradisional Penthul Melikan untuk guru.

Tari tradisional Penthul Melikan berpusat di Dusun Melikan Desa Tempuran Kecamatan Paron Kabupaten Ngawi. Tari Penthul Melikan diciptakan oleh sesepuh desa tersebut antara lain Kyai Munajahun, 
Hardjodinomo, Syahid, dan Yanudi pada tahun 1952. Tarian ini ditarikan dengan memakai topeng kayu yang melambangkan watak manusia yang berbeda-beda namun tetap bersatu dalam kerja.

Tari Penthul Melikan termasuk tari yang bermaksud untuk menyebarkan agama Islam. Penciptaan tari Penthul Melikan sesuai dengan keadaan masyarakat pada waktu itu yang serba mistik dan mempunyai kepercayaan tentang kemampuan indera keenam yang memungkinkan seseorang berkomunikasi dengan masa lampau dari zaman kejayaan Kediri (Literatur Hari Jadi Ngawi 7 Juli 1358 M).

Sanggar Penthul Melikan yang berada di Dusun Melikan Desa Tempuran Kecamatan Paron Kabupaten Ngawi ini merupakan sanggar khusus untuk mengajarkan tari tradisional Penthul Melikan yang ada di Ngawi. Sanggar ini memiliki jumlah anak didik yang cukup banyak meski dari berbagai kalangan usia. Terdapat anak didik dari kalangan usia dini, usia sekolah dasar, sekolah menengah pertama, dan sekolah menengah atas. Sanggar ini melakukan kegiatan pembelajaran tari setiap akhir pekan yaitu pada hari Sabtu dan Minggu. Selain untuk mengisi waktu libur anak sekolah, kegiatan pembelajaran tari ini sebagai sarana pelestarian budaya daerah, terutama budaya daerah Ngawi. Pada waktu tertentu, kegiatan pembelajaran tari tradisional Penthul Melikan lebih sering dilakukan yaitu pada waktu mendekati hari ulang tahun kota Ngawi, hari ulang tahun kemerdekaan Republik Indonesia, dan waktu kenaikan kelas. Pada waktu tersebut, banyak siswa dari berbagai sekolah yang meminta pelatih untuk mengajarkan tari tradisional Penthul Melikan untuk ditampilkan saat acara dilaksanakan.

Berdasarkan latar belakang tersebut, peneliti fokus pada pembelajaran tari pada kalangan anak usia dini usia 4-6 tahun. Diharapkan dari penelitian ini dapat diperoleh secara utuh tentang bagaimana pembelajaran tari tradisional Penthul Melikan mulai dari perencanaan, pelaksanaan, dan kendala-kendala yang dialami selama proses pembelajaran tari tradisional Penthul Melikan pada anak usia 4-6 tahun di sanggar Penthul Melikan Kabupaten Ngawi.

\section{Pembelajaran Tari}

Pembelajaran adalah proses interaksi peserta didik dengan pendidik dan sumber belajar pada suatu lingkungan belajar. Pembelajaran merupakan bantuan yang diberikan pendidik agar dapat terjadi proses pemerolehan ilmu dan pengetahuan, penguasaan kemahiran dan tabiat, serta pembentukan sikap dan kepercayaan pada peserta didik. Pembelajaran adalah pemberdayaan potensi peserta didik menjadi kompetensi. Kegiatan pemberdayaan ini tidak dapat berhasil tanpa ada orang yang membantu. Menurut Dimyati dan Mudjiono (Syaiful Sagala, 2011) pembelajaran adalah kegiatan guru secara terprogram dalam desain instruksional, untuk membuat belajar secara aktif, yang menekankan pada penyediaan sumber belajar.

Konsep pembelajaran menurut Syaiful Sagala (2011) adalah suatu proses dimana lingkungan seseorang secara disengaja dikelola untuk memungkinkan ia turut serta dalam tingkah laku tertentu dalam kondisi-kondisi khusus atau menghasilkan respons terhadap situasi tertentu. Pembelajaran pada hakekatnya merupakan proses interaksi antara siswa dengan lingkungannya, sehingga terjadi perubahan perilaku ke arah lebih baik. Selama proses pembelajaran, tugas guru yang paling utama adalah mengkondisikan lingkungan belajar agar menunjang terjadinya perubahan perilaku bagi siswa (Mulyasa, 2012). Berdasarkan uraian tersebut dapat disimpulkan bahwa pembelajaran adalah usaha sadar dari guru untuk membuat siswa belajar, yaitu terjadinya perubahan tingkah laku pada diri siswa yang belajar 
dimana perubahan itu dengan didapatkannya kemampuan baru yang berlaku dalam waktu yang relative lama dan karena adanya usaha.

Pengembangan kreativitas anak dapat dilakukan dengan melakukan eksplorasi gerak yang dilakukan oleh anak. Melalui eksplorasi anak-anak dapat mencoba dan menemukan berbagai ragam gerak yang dikehendaki. Kemampuan yang sangat mendasar dari fisik anak usia dini dapat dilihat dari kemampuan dalam melakukan gerakan keseimbangan, lokomotor, kecepatan, adanya perubahan ekspresi, teknik, bisa mengendalikan tubuh dan dapat melakukan gerak energik melalui koordinasi dengan anggota tubuh lainnya. Tari dalam Kamus Besar Bahasa Indonesia (1991) didefinisikan sebagai gerakan badan (tangan dan sebagainya) yang berirama dan biasanya diiringi bunyi-bunyian (musik, gamelan, dan sebagainya). Tari merupakan gerak seluruh tubuh atau sebagian tubuh melalui gerakan ritmis yang terdiri dari pola kelompok atau individual dan disertai ekspresi maupun ide-ide tertentu. Dari pengertian tersebut dapat disimpulkan bahwa tari merupakan sebuah seni atau kesenian yang berupa gerakan badan yang ritmis sebagai ekspresi jiwa dengan iringan musik sehingga menimbulkan keindahan.

Tari dalam dimensi pendidikan akan memberi warna dan arah pada pembentukan pengetahuan, sikap dan keterampilan gerak. Hal ini disebabkan karena pembelajaran tari tidak hanya mengembangkan kompetensi motorik semata, akan tetapi kompetensi afektif dan kognitif. Ada empat fungsi pembelajaran tari pada anak usia dini. Purnomo (2013) mengemukakan keempat fungsi itu yaitu: (1) Mengembangkan kompetensi intelektual. Hal ini disebabkan pada saat menari anak harus mempu secara kognitif, yaitu untuk memahami, mengerti, mensintesa bahkan mengevaluasi gerak yang dilakukan. Sedangkan dari ranah afektif anak dituntut untuk mampu bersikap positif menerima estetika tari. Sementara dari ranah psikomotorik anak dituntut untuk mampu melakukan gerak secara terampil, tepat dengan irama yang mengiringinya. (2) Wahana sosialisasi. Tari dalam dimensi pendidikan juga merupakan wahana sosialisasi bagi anak, terutama sewaktu menari dalam bentuk kelompok. Setiap anak dituntut untuk mampu bekerjasama. Hal ini diperlukan untuk memberi kekompakan gerak sewaktu menari. Sosialisasi melalui tari akan berdampak pada rasa percaya diri pada anak. (3) Wahana cinta lingkungan. Selain mengembangkan kompetensi intelektual dan kompetensi bersosialisasi, tari pendidikan juga mampu mengembangkan cinta lingkungan pada anak. Ini dapat dilakukan dengan cara memberi pengertian tentang makna tari yang terkandung didalamnya. Dengan demikian anak tidak hanya hafal dalam menari melainkan dapat menanamkan sejak dini untuk mencintai lingkungan alam sekitar. (4) Pengembangan kreativitas. Pengembangan kreativitas ini dapat dilakukan dengan melakukan eksplorasi gerak yang dilakukan oleh anak. Melalui eksplorasi anak-anak dapat mencoba dan menemukan berbagai ragam gerak yang dikehendaki.

Pembelajaran seni tari merupakan salah satu pembelajaran yang mampu memenuhi tujuan pembelajaran. Jazuli dalam buku Paradigma Kontekstual Pendidikan Seni menyatakan "Pembelajaran seni tari adalah suatu proses usaha yang dilakukan seseorang untuk memperoleh suatu perubahan sikap dan tingkah laku sebagai hasil pengalaman berkesenian dan berinteraksi dengan budaya lingkungan untuk mencapai tujuan tertentu “ (Jazuli, 2008). Pembelajaran seni tari yang berkualitas akan terwujud jika terjadi proses belajar mengajar yang berkualitas. Melalui interaksi antara pendidik dan peserta didik dalam pengajaran yang bersifat edukatif, pendidik harus mampu menciptakan proses pengajaran dalam suasana kegiatan belajar mengajar yang baik, agar tercipta proses pembelajaran yang efektif dan berkualitas. 
Pembelajaran seni tari yang berkualitas berakar dari adanya strategi pembelajaran yang telah dirrancang untuk mencapai kompetensi pembelajaran. Melalui pembelajaran seni tari yang berkualitas peserta dididik akan menyadari terjadi perubahan dalam keterampilan, pengetahuan, serta tingkah lakunya.

Hal-hal yang harus diperhatikan dalam pembelajaran tari bagi anak usia dini yaitu karakteristik gerak tari bagi anak usia dini. Secara umum karakteristik gerak bagi anak usia dini, yaitu: menirukan, manipulasi (perlakuan), dan bersahaja.

Berdasarkan uraian di atas pembelajaran tari adalah usaha sadar dari guru untuk membuat siswa belajar melalui gerakan- gerakan terarah sebagai ekspresi jiwa dengan iringan musik untuk menciptakan suatu keindahan.

\section{Tari Tradisional Penthul Melikan}

Tari tradisional Penthul Melikan yang berpusat di dusun Melikan Desa Tempuran Kecamatan Paron Kabupaten Ngawi ini diciptakan oleh sesepuh desa tersebut antara lain Kyai Munajahun, Hardjodinomo, Syahid, dan Yanudi pada tahun 1952. Dulunya tari ini diciptakan pertama kali sebagai simbolis rasa syukur dan luapan kegembiraan karena telah selesainya pembuatan jembatan di daerah Tempuran. Namun sekarang tari Penthul Melikan menjadi sarana hiburan untuk masyarakat Ngawi. Biasanya pada hari besar, misalnya Hari Jadi Kota Ngawi dan Hari Ulang Tahun Kemerdekaan Republik Indonesia. Tari Penthul Melikan juga terpengaruh gaya Reog Ponorogo. Hal ini ditandai dengan adanya tingkat kesamaan pada kostum asli Penthul Melikan yaitu pakaian hitam-hitam dan celana Bujang Ganong.

Tari tradisional Penthul Melikan termasuk tari yang bermaksud untuk menyebarkan agama Islam, seperti halnya di Sumatera Utara ada tari Saman, di Purworejo ada Dolalak. Penciptaan tari Penthul Melikan sesuai dengan keadaan masyarakat pada waktu itu yang serba mistik, mempunyai keyakinan dan kepercayaan tentang kemampuan indera keenam yang memungkinkan seseorang berkomunikasi dengan masa lampau, dari zaman kejayaan Kediri (Literatur Hari Jadi Ngawi 7 Juli 1358 M). Karena pada waktu itu masyarakat sekitar masih kuat akan animisme dan dinamismenya, walaupun sudah ada sebagian yang beragama Islam. Jadi, materi Tari Penthul Melikan diciptakan dengan perpaduan antara pengaruh Hindu Kuno pada zaman kerajaan Kediri dan gamelan Jawa yang sedikit mirip dengan Laras Madyo yang pada dasarnya merupakan Kesenian Jawa yang Islami.

Tari tradisional Penthul Melikan merupakan tari yang menggunakan topeng setengah jadi yang terbuat dari kayu. Kenapa dikatakan setengah jadi? dikarenakan topeng tersebut permukaannya masih dalam tahap penggarapan secara kasar tidak seperti topengtopeng pada umumnya. Hal ini yang menjadi ciri khas topeng Penthul Melikan. Menggunakan sarana topeng pada tarian Penthul Melikan menyimbolkan bahwa karakter atau watak setiap orang berbeda-beda tetapi tetap bersatu dalam kerja.

Tari tradisional Penthul Melikan diiringi gending Jawa. Gerak tarian dimaksudkan sebagai lambang menyembah Tuhan Yang Maha Esa dan mengajak manusia untuk hidup bersatu demi terwujudnya suasana aman dan damai. Seperti gerakan tari dengan tangan yang mengacungkan telunjuk ke atas, dua tangan menengadah kedepan, tangan mengacungkan jari telunjuk di atas kepala dengan gerakan melingkar, tangan dirangkai, dan sebagainya dengan membentuk formasi setengah lingkaran.

Pembelajaran tari tradisional Penthul Melikan memiliki kelebihan dan kekurangan. Kelebihan pembelajaran tari tradisional Penthul Melikan diantaranya (Yeti Rahmawati, 2018) yaitu: dapat dinikmati oleh semua usia, mencerminkan budaya asli daerah, dan memiliki 
beberapa fungsi. Sedangkan kekurangannya yaitu: tidak mengikuti jaman/ up to date, tidak banyak diminati, dan pelestarian karyanya lebih sedikit dibandingkan dengan tari modern.

\section{METODE}

Penelitian ini mengambil latar di sanggar Penthul Melikan. Penelitian dilakukan dengan pendekatan kualitatif deskriptif dengan menitik beratkan pada proses pembelajaran tari tradisional Penthul Melikan pada anak usia 4-6 tahun di Sanggar Penthul Melikan selama bulan Januari hingga Maret 2019. Bogdan dan Taylor (Basrowi dan Suwandi, 2008) menyatakan bahwa penelitian kualitatif adalah salah satu prosedur penelitian yang menghasilkan data deskriptif berupa ucapan atau tulisan dan perilaku orang-orang yang diamati. Penelitian kualitatif adalah penelitian yang pemecahan masalahnya dilakukan dengan menggunakan data empiris. Sumber data penelitian ini didapat dari observasi anak usia 4-6 tahun yang mengikuti pembelajaran tari tradisional Penthul Melikan di sanggar Penthul Melikan berjumlah 20 anak. Sumber data tersebut diperkuat dengan dokumen wawancara dari pihak penyelenggara pembelajaran tari tradisional Penthul Melikan dan dokumentasi.

Teknik pengumpulan data dilakukan dengan observasi, wawancara, dan studi dokumentasi. Observasi dilakukan dengan mengamati proses pembelajaran tari di sanggar Penthul Melikan. Wawancara dilakukan kepada pelatih tari yang terdiri dari dua pelatih. Untuk memperoleh data yang pasti (valid) pengumpulan data dilakukan dengan teknik triangulasi yaitu dengan menggunakan berbagai sumber dan teknik pengumpulan data. Setelah data terkumpul, maka langkah selanjutnya yaitu menganalisis data, teknik analisis data digunakan untuk menganalisis data yang telah diperoleh untuk ditarik kesimpulan.

Teknis analisis yang digunakan adalah analisis data kualitatif yang mengikuti konsep Miles dan Huberman yang terdiri dari pengumpulan data, reduksi data, dan penarikan kesimpulan/ verifikasi.

\section{HASIL DAN PEMBAHASAN}

Tari Penthul Melikan yang berpusat di dusun Melikan Desa Tempuran Kecamatan Paron Kabupaten Ngawi ini diciptakan oleh sesepuh desa tersebut antara lain Kyai Munajahun, Hardjodinomo, Syahid, dan Yanudi pada tahun 1952. Tari tradisional Penthul Melikan termasuk tari yang bermaksud untuk menyebarkan agama Islam. Penciptaan tari Penthul Melikan sesuai dengan keadaan masyarakat pada waktu itu yang serba mistik, mempunyai keyakinan dan kepercayaan tentang kemampuan indera keenam yang memungkinkan seseorang berkomunikasi dengan masa lampau. Adapun langkah-langkah pembelajaran tari tradisional Penthul Melikan adalah sebagai berikut: (Harmin Etikasari Karimah, 2017):

1) Gerakan pertama yaitu gerakan rangkaian tangan, gerakan tersebut adalah gerakan dimana tangan penari dikaitkan. Tangan kiri penari dikaitkan dengan tangan kanan penari disebelahnya kemudian tangan mereka berada di pinggang dan posisi kaki agak terbuka. Kemudian lutut para penari tersebut ditekuk sehingga penari bergerak ke atas ke bawah.

2) Gerakan kedua yaitu jari mengembang ke hidung, bentuk gerakan tersebut adalah jari tangan terbuka kemudian jari tangan kiri menyentuh hidung pada bagian jari jempol kemudian jari tangan kanan berada di depan jari tangan kiri. Jari jempol tangan kanan menyentuh jari kelingking tangan kiri. Dalam melakukan gerakan ini sama dengan gerakan pada bagian pertama tadi yaitu lutut ditekuk kemudian penari bergerak ke atas ke bawah. Dalam gerakan ini para penari sambil mengatakan "OO AA".

3) Gerakan ketiga adalah gerak tangan yang menengadah ke atas, bentuk dari gerakan ini adalah tangan lurus ke depan berbentuk siku-siku dan kedua telapak tangan menengadah ke atas. Kemudian diikuti 
dengan gerakan kaki kiri maju kemudian kembali lagi digantikan kaki kanan yang maju. Pada gerakan ini para penari mengucapkan kata "Maju bung".

4) Gerakan keempat adalah gerak tangan sikusiku kemudian serong ke kiri. Bentuk gerakan ini hampir sama dengan gerakan ketiga yaitu tangan lurus ke depan berbentuk siku-siku dan kedua telapak tangan menengadah ke atas kemudian kaki berjalan di tempat dan perlahan berputar ke kiri. Dalam gerakan ini para penari mengucapkan kata "selalu".

5) Gerakan kelima yaitu gerakan jari telunjuk mengacung. Bentuk dari gerakan ini adalah jari telunjuk dari tangan kanan mengacung ke atas, dan tangan kiri di bawah. Kemudian jari telunjuk tersebut diputar di atas kepala.

6) Gerakan keenam adalah jari jempol mengacung. Bentuk dari gerakan ini adalah tangan kanan lurus ke depan kemudian sambil mengacungkan jari jempol, sedangkan tangan kiri turun ke bawah dan kaki kanan berada di depan sambil berjalan di tempat. Dalam gerakan ini para penari mengucapkan "sudah jadi ".

7) Gerakan ketujuh adalah gerakan tangan yang mengembang atau terbuka ke atas. Bentuk dari gerakan ini adalah kedua tangan lurus ke atas kepala kemudian telapak tangan dibuka ke atas. Setelah itu penari berjalan di tempat dan perlahan memutar ke kiri. Dalam gerakan memutar ini para penari mengucapkan kata "aku suka”.

\section{Perencanaan Pembelajaran Tari Tradisional} Penthul Melikan pada Anak Usia 4-6 Tahun di Sanggar Penthul Melikan

Perencanaan pembelajaran tari tradisional Penthul Melikan di sanggar Penthul Melikan yaitu menentukan tujuan, alat dan bahan, alokasi waktu, materi, dan langkah-langkah pembelajaran.
Pembelajaran tari tradisional Penthul Melikan di sanggar Penthul Melikan memiliki tujuan untuk menginformasikan kepada masyarakat umum tentang keaslian tari tradisional Penthul Melikan. Selain itu pembelajaran tari tradisional Penthul Melikan bertujuan untuk menanamkan makna yang terkandung dalam gerakan tari dan assesoris yang digunakan agar anak dapat menerapkan makna tersebut dalam kehidupan sehari-hari.

Penyediaan alat dan bahan dalam pembelajaran tari tradisional Penthul Melikan disesuaikan dengan keperluan yang dipakai saat pembelajaran. Peralatan yang terdapat pada tari tradisional Penthul Melikan yaitu buku pedoman, alat musik pengiring/rekaman vidio, topeng penthul melikan, dan pakaian. Saat pembelajaran di sanggar, peralatan yang digunakan yaitu buku panduan, rekaman vidio, dan topeng. Sedangkan alat musik pengiring yang terdiri dari bedug, kendang, kenong, dan jerr/simbal serta pakaian tari hanya digunakan saat pentas di suatu acara.

Waktu yang digunakan untuk dapat menguasai gerakan tari tradisional Penthul Melikan yaitu sekitar tiga sampai empat kali latihan, dimana setiap gerakan dapat dilakukan selama 15 menit. Pembelajaran tari tradisional Penthul Melikan di sanggar Penthul Melikan tidak hanya mengajarkan tentang gerakan tari saja, melainkan juga diajarkan tentang makna yang terkandung dalam setiap gerakan tari tradisional Penhul Melikan agar anak dapat mengaplikasikannya dalam kehidupan seharihari.

Langkah-langkah pembelajaran tari tradisional Penthul Melikan di sanggar Penthul Melikan yaitu pembukaan dengan mengkondisikan anak, melatih gerakan yang berjumlah tujuh gerakan pada tari tradisional Penthul Melikan, dan penutup dengan memberi pesan kepada anak. Gerakan I pada tari tradisional Penthul Melikan yaitu bergandengan tangan, gerakan II "OO AA", gerakan III "Maju 
Bung”, gerakan IV "Selalu”, gerakan V jari telunjuk mengacung ke atas, gerakan VI "Sudah Jadi”, dan gerakan VII “Aku Suka”.

\section{Pelaksanaan Pembelajaran Tari Tradisional Penthul Melikan pada Anak Usia 4-6 Tahun di Sanggar Penthul Melikan}

Pelaksanaan proses pembelajaran tari tradisional Penthul Melikan pada anak usia 4-6 tahun di sanggar Penthul Melikan meliputi: kegiatan pembukaan, kegiatan inti, dan kegiatan penutup. Pada kegiatan pembukaan pelatih melihat kesiapaan anak untuk mengikuti pembelajaran tari yang akan dilaksanakan. Dalam kegiatan pembukaan, anak dengan penuh semangat menjawab salam yang diucapkan pelatih. Anak juga antusias menjawab saat ditanya pelatih terkait pembelajaran yang telah dilakukan sebelumnya. Pelatih mengatur barisan anak-anak, selanjutnya anak melakukan gerakan tari tradisional Penthul Melikan secara bersamasama.

Pada kegiatan inti pelaksanaan pembelajaran tari tradisional Penthul Melikan pada anak usia 4-6 tahun di sanggar Penthul Melikan pelatih menyampaikan kepada anak didik tentang materi yang akan dipelajari, yaitu materi berupa gerakan tari maupun makna yang terkandung dalam gerakan tari tradisional Penthul Melikan. Selain mengajarkan gerakan tari tradisional Penthul Melikan yang terdiri dari tujuh gerakan, pelatih juga menyampaikan materi terkait makna yang terkandung dalam gerakan tari tradisonal Penthul Melikan dengan maksud anak dapat melaksanakan makna yang terkandung didalamnya. Setelah pelatih menyampaikan materi yang akan dipelajari, selanjutnya anak memperhatikan vidio rekaman yang diperlihatkan oleh pelatih dengan seksama. Pelatih mencontohkan gerakan tari tradisional Penthul Melikan yang terdiri dari tujuh gerakan secara satu persatu. Sebelum pelatih menyampaikan makna gerakan yang terkandung dalam gerakan tari tradisional Penthul Melikan, pelatih bertanya bagaimana gerakan dan makna yang terkandung dalam gerakan tersebut untuk menggali pengetahuan anak. Anak menjawab pertanyaan pelatih dengan penuh semangat. Saat pelatih menyampaikan materi terkait makna gerakan tari, anak memperhatikan dengan serius dan bertanya jika terdapat hal yang belum mereka ketahui.

Kegiatan penutup, pelatih bersama-sama dengan anak membuat rangkuman/simpulan pelajaran yang telah dilakukan, melakukan refleksi terhadap kegiatan yang sudah dilaksanakan, memberikan umpan balik terhadap proses dan hasil pembelajaran, dan merencanakan kegiatan tindak lanjut. Pelatih memberikan penguatan/kesimpulan terhadap pembelajaran yang telah dilaksanakan dan memberikan pesan terkait materi pembelajaran yang telah dilaksanakan.

\section{Kendala Pembelajaran Tari Tradisional Penthul Melikan pada Anak Usia 4-6 Tahun di Sanggar Penthul Melikan}

Kendala yang dialami dalam poses pembelajaran tari tradisional Penthul Melikan di sanggar Penthul Melikan dipengaruhi oleh faktor internal dan faktor eksternal. Adapun faktor internal diantaranya: kurangnya komunikasi antara pelatih dan anak, kemampuan anak yang berbeda, dan terdapat gerakan yang sulit. Ketika pelatih/anak ada kegiatan mendadak dan mereka tidak bisa memberi informasi padahal pelatih/anak sudah di sanggar maka pembelajaran tari tidak dapat dilaksanakan. Dalam pembelajaran tari tradisional Penthul Melikan telah ditentukan waktu untuk anak dapat menguasai gerakan tari tradisional Penthul Melikan, tetapi masih ada anak yang belum dapat menguasai gerakan sesuai waktu yang telah ditentukan. Selain itu, dalam gerakan tari tradisional Penthul Melikan terdapat gerakan yang sulit untuk cepat dapat dikuasai anak, yaitu gerakan gerakan III "Maju Bung” dimana anak 
harus dapat mengkoordinasikan antara gerakan tangan dan kaki.

Faktor eksternal diantaranya cuaca dan pelaporan hasil belajar anak. Karena sanggar Penthul Melikan berada di halaman rumah, maka jika turun hujan maka pembelajaran tari tidak dapat dilaksanakan. Pembelajaran dapat dialihkan di serambi/teras rumah dengan materi pembelajaran pengenalan makna gerakan tari tradisional Penthul Melikan hanya saja kurang maksimal. Untuk pelaporan hasil belajar anak, di sanggar ini belum memiliki laporan secara tertulis yang dapat disampaikan kepada orang tua anak didik yang mengikuti pembelajaran tari di sanggar Penthul Melikan. Pelatih hanya menyampaikan secara lisan kepada orang tua terkait hasil belajar anak. Hasil di atas sejalan dengan paparan John (2014) yang menyatakan bahwa hasil belajar peserta didik dipengaruhi oleh, waktu yang tersedia untuk mempelajari bahan pelajaran yang telah ditentukan, usaha yang dilakukan peserta didik untuk menguasai bahan pelajaran, bakat yang dimiliki peserta didik, kualitas pengajaran atau tingkat kejelasan pengajarannya, kemampuan peserta didik untuk mendapat manfaat yang optimal dari keseluruhan proses pembelajaran yang sedang dihadapi.

\section{Kesimpulan}

Pembelajaran tari tradisional Penthul Melikan di Sanggar Penthul Melikan terutama pada anak usia 4-6 tahun pada perencanaan pembelajaran pelatih mempersiapkan tujuan pembelajaran, alat dan bahan, alokasi waktu serta materi pembelajaran. Pelaksanaan terdiri dari kegiatan pembuka, kegiatan inti, dan kegiatan penutup. Kendala yang dialami selama proses pembelajaran diantaranya kurang komunikasi, perbedaan kemampuan anak, terdapat gerakan yang sulit, cuaca, dan pelaporan hasil belajar anak. Pembelajaran tari tradisional Penthul Melikan pada anak usia 4-6 tahun di sanggar Penthul Melikan dapat dilaksanakan dengan baik meski terdapat kendala selama proses pembelajaran.

Anak lebih aktif dalam pembelajaran tari tradisional Penthul Melikan untuk melestarikan budaya daerah terutarama kesenian dari daerah Ngawi. Pelatih dapat menggunakan cara yang lebih efektif dalam mengajaran tari tradisonal Penthul Melikan kepada anak khususnya anak usia dini agar anak dapat mempelajari tari tradisonal Penthul Melikan dengan senang. Seniman dapat melestarikan budaya daerah dengan menghidupkan kembali keseniankesenian daerah dan membuat kreasi kesenian daerah dengan tidak menghilangkan kebudayaan asli. Sehingga anak dapat mengetahui kebudayaan asli daerah dan hasil kreasi agar tidak salah dalam mempelajari kebudayaan daerah. Saran dapat mengacu pada tindakan praktis, pengembangan teori baru, dan/atau penelitian lanjutan.

\section{DAFTAR PUSTAKA}

Basrowi dan Suwandi. (2008). Memahami Penelitian Kualitatif. Jakarta: Rineka Cipta

Harmin Etikasari Karimah. (2017). Makna Simbol Tari Penthul Melikan di Tempuran Paron Ngawi. Jurnal Studi Sosial Universitas PGRI Madiun. Vol. 2 No. 1, Juli 2017.

Hartono. (2012). Pembelajaran Tari Anak Usia Dini. Semarang: Unnes Pres.

Hidayat, Robby. (2005). Wawasan Seni Tari Pengetahuan Praktis Bagi Guru Seni Tari. UPPT: UNM

Jazuli, M. (2008). Paradigma Kontekstual Pendidikan Seni. Semarang: Unisba University Press.

John, Afifi. (2014). Inovasi-inovasi Kreatif Manajemen Kelas dan Pengajaran Efektif. Jogjakarta: Diva Press.

Juntika Nurikhsan. (2007). Materi Pokok Perkembangan Peserta Didik. Bandung: UPI.

Kamus Besar Bahasa Indonesia. (1991). Departemen Pendidikan dan Kebudayaan. Balai Pustaka. 
Mulyasa. (2012). Manajemen Paud. Bandung: PT. Remaja Rosda Karya.

Purnomo, Eko. (2013). Mengembangkan Tari Kreatif Melalui Model pembelajaran Berbasis Kecerdasan Jamak. Jakarta: Kemdikbud

Syaiful Sagala. (2011). Konsep dan Makna Pembelajaran. Bandung: Alfabeta

Yayat Nursantara. (2007). Seni Budaya untuk SMA Kelas X. Jakarta: Erlangga

Yeti Rahmawati. (2018). Tari Pentul Melikan Kabupaten Ngawi Sebagai Media Pendidikan Karakter. Jurnal Pendidikan Sejarah Universitas Negeri Surabaya. Vol. 6 No. 2, Juli 2018 